\title{
EFFECT OF ETHRANE ANAESTHESIA AND SURGICAL OPERATION ON ADRENOCORTICAL FUNCTION
}

\author{
T. Oyama, M.D., A. Matsuzi, M.D., and M. Kudo, B.S.
}

THE PRESENT STUDY was undertaken to investigate the effect of Ethrane, a recently introduced halogenated ether, and of surgical operation on adrenocortical function by determining cortisol (= hydrocortisone) in the plasma of peripheral venous blood in man. Although other anaesthetic agents have been shown to have some influence on plasma free cortisol levels in man, ${ }^{1-4}$ information on the effect of $\bar{E}$ thrane anaesthesia has been scant. Only Dobkin $e t a l^{5}$ have reported a rise of mean plasma cortisol levels in patients undergoing Ethrane anaesthesia.

\section{METHOD}

Fifteen patients ranging from 25 to 59 years of age were studied. All underwent abdominal operations. The average operating time was 2 hours and 42 minutes, and the mean anaesthetic time was 3 hours and 45 minutes. The type of operation and the ages of the patients are shown in Table I. In none of them was there any clinical evidence of endocrine disorder or impaired renal or hepatic function, nor had any received ACTH or corticosteroid compounds.

Each patient was premedicated with pentobarbitone $100 \mathrm{mg}$ orally 1 th hours before the induction of anaesthesia, atropine $0.5 \mathrm{mg}$ and meperidine $35 \mathrm{mg}$ intramuscularly 1 hour prior to induction. Anaesthesia was induced at $8.30 \mathrm{a} . \mathrm{m}$. with an inspired Ethrane concentration of 1.5 to 4.0 per cent delivered from a Fluotec Mark II Vaporizer, combined with nitrous oxide $(2 \mathrm{~L} / \mathrm{min})$ and oxygen $(2 \mathrm{~L} / \mathrm{min})$. After endotracheal intubation had been carried out following intravenous succinylcholine $40 \mathrm{mg}$, anaesthesia was maintained with Ethrane ( 1.5 to 3.5 per cent) in nitrous oxide ( $2 \mathrm{~L} / \mathrm{min}$ ) and oxygen ( $2 \mathrm{~L} / \mathrm{min}$ ). Tubocurarine 15 to $24 \mathrm{mg}$ was injected as required in divided doses.

Ventilation was controlled or assisted intermittently throughout the procedure. A moderate depth of anaesthesia was maintained as judged by clinical criteria and based on physical signs including blood pressure, pulse rate, and somatic reflex responses to the surgical stimulation. Low molecular weight dextran $500 \mathrm{ml}$ was infused throughout the procedure until blood loss exceeded $300 \mathrm{ml}$, when whole blood was transfused. Eight blood samples were obtained from each patient. (1) Immediately before induction of anaesthesia, (2) 15 minutes after induction of anaesthesia, (3) 30 minutes after the start of anaesthesia, (4) 15, 30, 60, and 120 minutes after the start of the operation, and (5) in the recovery room.

Three $\mathrm{ml}$ of venous blood was collected on each occasion into a heparinized syringe. One ml of plasma was used for cortisol assays according to the method of

\footnotetext{
- Department of Anaesthesia, Hirosaki University School of Medicine, Hirosaki, Aomori-Ken,
} Japan. 
TABLE I

Patients Studied and Operations Performed

\begin{tabular}{|c|c|c|c|c|c|}
\hline Case no. & Age & $\operatorname{Sex}$ & Operation & Op. Titthe & Anaes. Time \\
\hline $\begin{array}{r}1 \\
2 \\
3 \\
4 \\
5 \\
6 \\
7 \\
8 \\
9 \\
10 \\
11 \\
12 \\
13 \\
14 \\
15\end{array}$ & $\begin{array}{l}25 \\
59 \\
25 \\
42 \\
46 \\
39 \\
39 \\
47 \\
28 \\
39 \\
54 \\
49 \\
57 \\
36 \\
45\end{array}$ & $\begin{array}{l}\mathbf{F} \\
\mathbf{M} \\
\mathbf{M I} \\
\mathbf{F} \\
\mathbf{F} \\
\mathbf{M} \\
\mathbf{F} \\
\mathbf{F} \\
\mathbf{M} \\
\mathbf{F} \\
\mathbf{F} \\
\mathbf{F} \\
\mathbf{F} \\
\mathbf{F} \\
\mathbf{F}\end{array}$ & $\begin{array}{l}\text { Simple hysterectomy } \\
\text { Prostatectomy } \\
\text { Gastrectomy } \\
\text { Simple hysterectomy } \\
\text { Oophorectomy } \\
\text { Gastrectomy } \\
\text { Simple hysterectomy } \\
\text { ibid. } \\
\text { Cholecystectomy } \\
\text { Pyeloureterostomy } \\
\text { Cholecystectomy } \\
\text { Simple hysterectomy } \\
\text { ibid. } \\
\text { ibid. } \\
\text { It nephrectomy }\end{array}$ & $\begin{array}{l}1^{\circ} 25^{\prime} \\
2^{\circ} 00^{\prime} \\
2^{\circ} 05^{\prime} \\
1^{\circ} 55^{\prime} \\
2^{\circ} 10^{\prime} \\
2^{\circ} 00^{\prime} \\
2^{\circ} 40^{\prime} \\
2^{\circ} 50^{\prime} \\
3^{\circ} 45^{\prime} \\
2^{\circ} 45^{\prime} \\
5^{\circ} 50^{\prime} \\
2^{\circ} 05^{\prime} \\
2^{\circ} 25^{\prime} \\
4^{\circ} 20^{\prime} \\
2^{\circ} 20^{\prime}\end{array}$ & $\begin{array}{l}2^{\circ} 10^{\prime} \\
3^{\circ} 05^{\prime} \\
3^{\circ} 25^{\prime} \\
2^{\circ} 40^{\prime} \\
3^{\circ} 0 \mathbf{9}^{\prime} \\
3^{\circ} 15^{\prime} \\
3^{\circ} 00^{\prime} \\
5^{\circ} 00^{\prime} \\
5^{\circ} 20^{\prime} \\
3^{\circ} 55^{\prime} \\
6^{\circ} 30^{\prime} \\
2^{\circ} 50^{\prime} \\
3^{\circ} 10^{\prime} \\
5^{\circ} 50^{\prime} \\
3^{\circ} \mathbf{1 0}\end{array}$ \\
\hline Mean & & & & $2^{\circ} 42^{\prime}$ & $3^{\circ} 45^{\prime}$ \\
\hline
\end{tabular}

TABLE II

Arterial Blood Gas Analyses Dertng Ëthrane-Nitrous Oxide Anesthesia

\begin{tabular}{|c|c|c|c|c|}
\hline Time & $\mathrm{Pog}_{2}$ & $\mathbf{P}_{\mathrm{eO}_{2}}$ & $\mathrm{pH}$ & B.E. \\
\hline $\begin{array}{l}\text { Pre-ind. } \\
\text { Anaes. } 15 \text { min. } \\
\text { Anaes. } 30 \text { min. } \\
\text { Op. } 30 \text { min. } \\
\text { Op. } 1 \text { h. } \\
\text { Recovery }\end{array}$ & $\begin{array}{r}76.2 \pm 6.1 \\
203.8 \pm 13.2 \\
253.4 \pm 14.6 \\
238.1 \pm 24.2 \\
201.6 \pm 39.3 \\
121.9 \pm 19.8\end{array}$ & $\begin{array}{l}36 \pm 2.4 \\
33 \pm 3.3 \\
32 \pm 2.6 \\
33 \pm 3.2 \\
32 \pm 2.5 \\
34 \pm 3.8\end{array}$ & $\begin{array}{l}7.38 \pm 0.2 \\
7.41 \pm 0.1 \\
7.42 \pm 0.2 \\
7.51 \pm 0.1 \\
7.42 \pm 0.2 \\
7.40 \pm 0.1\end{array}$ & $\begin{array}{l}+1.3 \pm 1.8 \\
+1.6 \pm 0.9 \\
+1.8 \pm 0.3 \\
-0.5 \pm 1.3 \\
-1.3 \pm 0.8 \\
+1.6 \pm 1.8\end{array}$ \\
\hline
\end{tabular}

Rudd et al. ${ }^{7} \mathrm{PaO}_{2}, \mathrm{PaCO}_{2}, \mathrm{pH}$, and base excess were deternined in arterial blood at $37^{\circ} \mathrm{C}$ by means of an Astrup ultra-micro analyzer with a Severinghats electrode. No evidence of hypoxia or hypercarbia was found during the procedure (Table II).

\section{Results}

The mean preanaesthetic plasma level of cortisol in the moming immediately prior to induction of anaesthesia was $10.4 \pm 0.6 \mu \mathrm{g}$ per $100 \mathrm{ml}$. It decreased signifcantly to $8.6 \mu \mathrm{g}$ per $100 \mathrm{ml}$ following 30 minutes of anaesthesia. Then, however, the mean plasma level of cortisol rose significantly to 16.1 up 30 minutes after the start of the operation. The elevation continues for 2 hours thereafter with a peak level $(26.1 \mu \mathrm{g}$ ) in the recovery room when the patient was awake and had recovered from anaesthesia (Figure 1).

\section{Discussion}

$\bar{E}$ thrane is a newly introduced halogenated ether, with properties not dissimilar to halothane. It appears superior to halothane however in the following respects; muscle relaxation can be achieved, induction and recovery are rapid, arterial blood pressure is stable and no effects on hepatic function have been demonstrated.

Ethrane anaesthesia alone for 30 minutes caused a reduction of plasma cortisol 


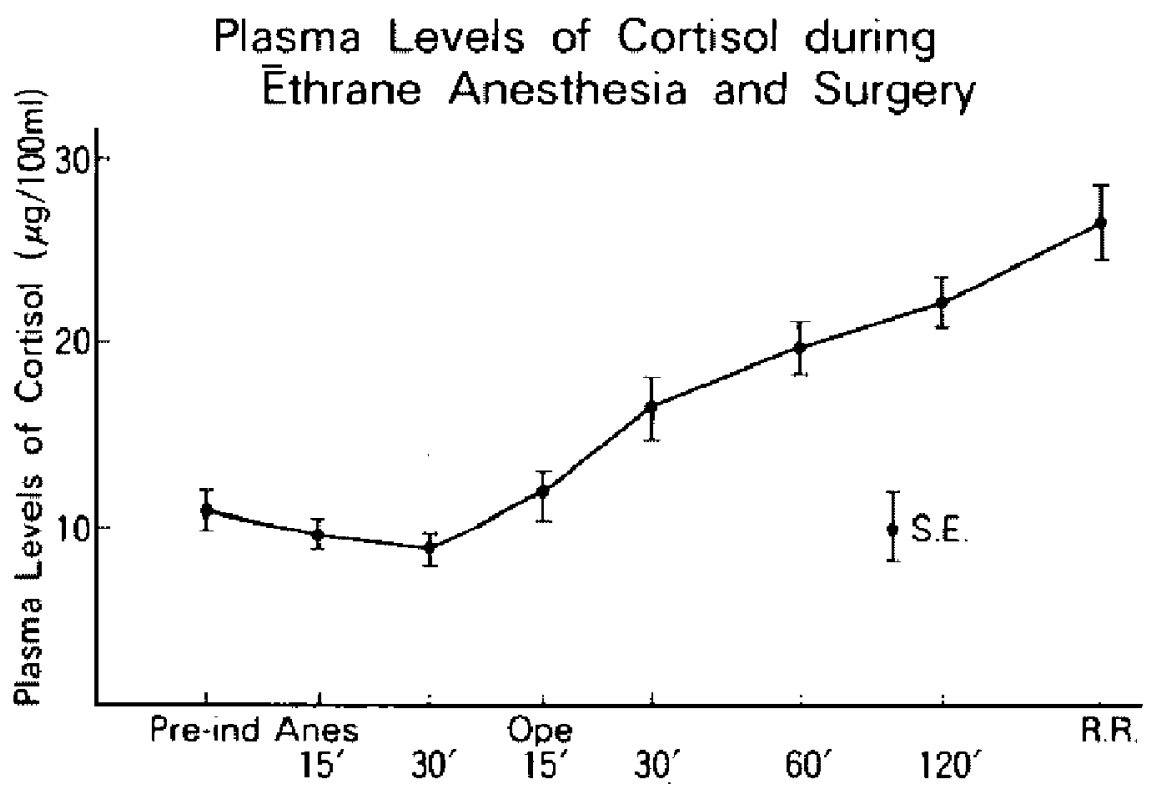

level in our study, but this was slight, amounting only to $1.8 \mu \mathrm{g}$ per $100 \mathrm{ml}$. After the start of operation it gradually and significantly increased, as occurs also with other anaesthetic agents. ${ }^{\text {- }}$ (

Clinically Ethrane resembles halothane, but its effect on adrenocortical function in man is comparable to that of methoxyflurane ${ }^{2}$ rather than to halothane. ${ }^{1}$ It is interesting to note that the chemical structure of $\bar{E}$ thrane also $\left(\mathrm{CHF}_{2}-\mathrm{O}-\mathrm{CF}_{2} \mathrm{CHFCl}\right)$ is similar to that of methoxyflurane $\left(\mathrm{CH}_{3}-\mathrm{O}_{-} \mathrm{CF}_{3} \mathrm{CHCl}_{2}\right)$.

Dobkin et al.5 have reported that plasma cortisol levels in patients receiving Ethrane anaesthesia for 30 minutes rose from a control level of $31.6 \pm 1.3 \mu \mathrm{g}$ per $100 \mathrm{ml}$ to $69.7 \pm 2.7 \mu \mathrm{g}$ per $100 \mathrm{ml}$. Their results differ from our study, and it is difficult to speculate on the reason for this discrepancy. The method of analysis of plasma cortisol levels and the method of administrating Ethrane might in part contribute to the difference between the two reports.

Hypoxia or hypercarbia have been reported to stimulate the adrenal cortex to judge from adrenocortical secretion ${ }^{11}$ or from peripheral cortisol levels ${ }^{12}$ in anaesthetized dogs. As shown in Table II, neither hypoxia nor hypercarbia occurred during $\bar{E}$ thrane anaesthesia in our study. Therefore these factors do not enter into our study.

Ethrane itself appears to be a non-stressing agent in terms of adrenocortical function in man. Therefore, this seems to be the anaesthetic of choice for patients with hyperadrenocortical function such as oceurs in Cushing's syndrome.

\section{SUMmary}

The present study was undertaken to investigate the effect of $\vec{E}$ thrane anaesthesia on adrenocortical function reflected by plasma cortisol levels in 15 surgical patients. 
TABLE III

Plasma Cortisol Levels During Ëthrane- ${ }_{2} \mathrm{O}$ Amaesthesia and Surgery $(\mu \mathrm{g} / 100 \mathrm{ml}$ )

\begin{tabular}{|c|c|c|c|c|c|c|c|c|}
\hline Case & Pre-ind. & Anaes. 15 & 30 & Op. 15 & 30 & 60 & 120 & R.R. \\
\hline $\begin{array}{c}1 \\
2 \\
3 \\
4 \\
5 \\
6 \\
7 \\
8 \\
9 \\
10 \\
11 \\
12 \\
13 \\
14 \\
15\end{array}$ & $\begin{array}{r}10.5 \\
14.8 \\
14.0 \\
11.3 \\
7.0 \\
11.0 \\
12.0 \\
7.5 \\
10.0 \\
10.5 \\
8.5 \\
12.5 \\
8.0 \\
9.5 \\
9.5\end{array}$ & $\begin{array}{r}12.5 \\
13.7 \\
14.0 \\
10.0 \\
10.0 \\
10.0 \\
8.5 \\
8.5 \\
8.5 \\
8.5 \\
7.5 \\
9.0 \\
7.5 \\
8.0 \\
7.5\end{array}$ & $\begin{array}{r}13.5 \\
12.1 \\
11.5 \\
8.7 \\
5.5 \\
11.0 \\
7.5 \\
8.0 \\
8.5 \\
8.0 \\
6.0 \\
8.0 \\
6.0 \\
7.0 \\
7.0\end{array}$ & $\begin{array}{r}19.5 \\
11.0 \\
10.0 \\
9.5 \\
18.0 \\
9.0 \\
8.0 \\
10.5 \\
8.5 \\
17.0 \\
8.0 \\
5.0 \\
14.5 \\
8.0\end{array}$ & $\begin{array}{r}26.0 \\
12.8 \\
23.0 \\
14.5 \\
11.5 \\
10.0 \\
18.0 \\
16.0 \\
16.5 \\
15.0 \\
21.5 \\
14.0 \\
13.5 \\
23.0 \\
6.5\end{array}$ & $\begin{array}{l}28.0 \\
19.0 \\
20.0 \\
17.0 \\
14.5 \\
22.5 \\
18.0 \\
19.0 \\
18.0 \\
17.0 \\
24.0 \\
17.0 \\
20.5 \\
24.0 \\
12.5\end{array}$ & $\begin{array}{l}\overline{20.0} \\
\overline{18.4} \\
\overline{28.0} \\
21.0 \\
22.0 \\
20.0 \\
20.0 \\
28.5 \\
21.0 \\
24.0 \\
26.0 \\
14.5\end{array}$ & $\begin{array}{l}29.0 \\
22.1 \\
16.5 \\
23.0 \\
15.5 \\
32.0 \\
30.0 \\
25.0 \\
24.0 \\
25.0 \\
43.5 \\
23.0 \\
33.0 \\
29.0 \\
20.5\end{array}$ \\
\hline Mean & 10.4 & 9.6 & 8.6 & 11.2 & 16.1 & 19.4 & 22.0 & 26.1 \\
\hline S.E. & 0.6 & 0.5 & 0.6 & 1.1 & 1.3 & 1.0 & 1.1 & 1.8 \\
\hline $\mathbf{P}$ & & 0.085 & 0.002 & 0.567 & 0.001 & 0.001 & 0.001 & 0.001 \\
\hline
\end{tabular}

$\bar{E}$ thrane anaesthesia alone for 30 minutes significantly but slightly decreased plasma cortisol level. However, it could not block the adrenocortical stimulation caused by surgical operation.

\section{RúsUMÉ}

La présente étude a été entreprise pour rechercher les effets de l'anesthésie à l'Ēthrane sur la fonction adrénocorticale reflétée par les niveaux de cortisol plasmatique chez 15 opérés. L'anesthésie à l'Ēthrane seul durant 30 minutes a diminué le niveau de cortisol plasmatique de façon évidente quoique légère. Cependant, cela ne pouvait pas bloquer la stimulation adrénocorticale causée par lopération chirurgicale.

\section{REFERENCES}

1. Oyama, T., Shibata, S., Matsumoto, F., Takicuchi, M., \&udo, T. Effects of halothane anaesthesia and surgery on adrenocortical function in man. Canad. Anaes. Soc. J., 15: 258 (1968).

2. Oyama, T., Shibata, S., Matsumoto, F., Matsuki, A., Kimuna, K., Takazawa, T., \& Kuno, T. Adrenocortical function related to methoxyflurane angesthesia and surgery in mar. Canad. Anaes. Soc. J, 15: 362 (1968).

3. Orama, T., Satto, T., Isomatse, T, Samejima, N., Uemura, $T$, \& Afimufa, A. Plasma levels of ACTH and cortisol in man during diethyl ether anesthesia and surgery. Anesthesiology, 29: 559 (1968).

4. Orama, T., Taxiguchi, M., AOKI, N., \& KuDO, T. Adrenocortical function related to thiopental-nitrous oxide-oxygen anesthesia and surgery in man. Anesth. \& Analg., 50:727 (1971).

5. Dobin, A.B., Hennich, R.G., Isfael, J.S., Levy, A.A., Nevil.le, J.F., \& Ounkasem, K. Clinical and Laboratory evaluation of a new inhalation agent: Compound 347 $\left(\mathrm{CHF}_{2}-\mathrm{O}-\mathrm{CF}_{2}-\mathrm{CHFCl}\right.$ ). Anesthesiology, 29: 275 ( 1968).

6. Dobmin, A.B., Nishoka, K., Gengaje, D.B., Kim, D.S., Evers, W, \& Israel, J.S. Ethrane (Compound 347 ) anesthesia: A clinical and laboratory reivew of 700 cases. Anesth \& Analg, 48: 477 (1969).

7. Bottx, C., Bhow, B., StAnlex, V, \& \&Epinen, C.R. Clinical experiences with compound 347, a halogenated anesthetic agent, Anesth. \& Analg, 47: 499 (1968). 
8. LFBowtr, M.H., BLIT, C.D., \& Diclon, J.B. Clinical investigation of compound 347 (Ethrane). Anesth. \&Analg, 49: 1 (1970).

0. RUDd, B.T., SAMpson, P., \& BRooke, N. A new flurometric method of plasma cortisol assay with a study of pituitary-adrenal function using metyrapone ( $\mathrm{SU}$ 4885). J. Endocr., 27: 317 (1963).

10. Oyama, T., Komura, K, Takazawa, T., Matsukt, A., Sato, K., Sarone, T., \& Jn, T. Effect of Ethrane anaesthesia and surgery on hepatic and renal function in man (to be published).

11. MarotTa, S.F., Hirai, K., \& ATKINs, G. Adrenocortical secretion in anesthetized dogs during hyperoxia hypoxia and positive pressure breathing. Proc. Soc. Expl. Biol. Med, 118: $922(1985)$

12. LAv, C. Effects of $\mathrm{O}_{2}-\mathrm{CO}_{2}$ changes on hypothalamo-hypophyseal-adrenocortical activation. Am. J. Physiol, 221: 607 ( 1971 ). 